ta-analysis of prospective studies. BMJ. 2016;353: i2716. https://doi.org/10.1136/bmj.i2716

35. Pyryeva E. A., Safronova A. I. The role of dietary fibers in the nutrition of the population. Voprosy pitaniya. Problems of Nutrition. 2019;88(6):511.

https://doi.org/10.24411/0042-8833-2019-10059

36. Gibson R., Eriksen R., Chambers E., Gao H., Aresu M. [et al.] Intakes and food sources of dietary fibre and their associations with measures of body composition and inflammation in UK adults: cross-sectional analysis of the airwave health monitoring study. Nutrients. 2019;11(8). https://doi.org/10.3390/nu11081839

37. Whole Grains Council. Whole Grain Statistics. Available at: https://wholegrainscouncil.org/newsroom/whole-grain-statistics. Accesses May, 12, 2020.

38. Wang Y., Duan Y., Zhu L., Fang Z., He L. [et al.] Whole grain and cereal fiber intake and the risk of type 2 diabetes: a meta-analysis. Int. J. Mol. Epidemiol. Genet. 2019;10(3):3846.

39. Spiricheva T. V., Spirichev V. B., Kodentsova V. M., Beketova N. A., Pereverseva O. G. [et al.] Effectiveness of use in preventive nutrition the food ptoducts with contents of pectin and vitamins. Voprosy pitaniya. - Problems of Nutrition. 2011;80(4):4755

40. Porter K., Hoey L., Hughes C., Ward M., McNulty H. Causes, Consequences and Public Health Implications of Low B-Vitamin Status in Ageing. Nutrients. 2016;8(11):725. https://doi.org/10.3390/nu8110725

41. Kodentsova V. M., Pogozheva A. V., Gromova O. A. Shikh E. V. Vitamin-mineral supplements in nutrition of adults. Voprosy pitaniya. - Problems of Nutrition. 2015; 84(6): 2433.

42. Kodentsova V. M. Vrzhesinskaya O A Risnik D. V. The analysis of domestic and international policy of food fortification with trace elements and salt iodization. Mikrojelementy $v$ medicine. - Trace Elements in Medicine. 2016;16(4):320.

https:/doi.org/10.19112/2413-6174-2015-16-4-3-20

43. Shipilov I. V., Belyaeva Y. S., Betekhtina V. A. [et al.] Experience of «Healthy nutrition» program implementation into system of preventive measures in major coal company. Medicina truda i promyshlennaya ekologiya. - Russian Journal of Occupational Health and Industrial Ecology. 2017;(10):5962.

\begin{abstract}
About autors:
Zaikina Inna Viktorovna, CMSc, Senior Researcher of the Department of medical-preventive and innovative technologies; tel.: +79172124250; e-mail: innaza2@mail.ru; https://orcid.org/0000-0003-4234-7056

Komleva Natalia Evgenievna, MD, DMSc, Professor, Head of the Department of medical-preventive and innovative technologies, Professor of the Department of neurology named after K. N. Tretyakov;

tel.: +79172170767; e-mail: NEKomleva@yandex.ru; https://orcid.org/0000-0001-5360-712X

Mikerov Anatoly Nikolayevitch, DBiolSc, Head of the Saratov Hygiene Medical Research Center, Professor of the Department of microbiology, virology and immunology;

tel.: +7(8452)927890; e-mail: niusgsar@mail.ru; https://orcid.org/0000-0002-0670-7918

Chekhonatsky Andrey Anatolevich, MD, Head of the Department of neurosurgery named after E. I. Babichenko; tel.: +7(8452)927890; e-mail: niusgsar@mail.ru; https://orcid.org/0000-0003-3327-1483

Chernyshkova Elena Vyacheslavovna, DSc, Assistant Professor, Head of the Department of foreign languages; tel.: +7(8452)927890; e-mail: niusgsar@mail.ru; tel.: +7(8452)227723; e-mail: chervy@mail.ru

Karpov Sergey Mikhailovich, MD, Professor, Head of the Department of neurology, neurosurgery and medical genetics; tel.: +7(8652)728412; e-mail: Karpov25@rambler.ru
\end{abstract}

\title{
NEW OPPORTUNITIES FOR IMMUNOLOGICAL CONTROL OF THE EFFECTIVENESS OF VACCINATION AGAINST COVID-19
}

Ketova G. G.

South Urals State Medical University, Chelyabinsk, Russian Federation

\section{НОВЫЕ ВОЗМОЖНОСТИ ИММУНОАОГИЧЕСКОГО КОНТРОАЯ ЭФФЕКТИВНОСТИ ВАКЦИНАЦИИ ПРОТИВ COVID-19}

\section{Г. Г. Кетова}

\section{Южно-Уральский госуАарственный меАицинский университет, Челябинск, Российская ФеАерация}

For citation: Ketova G. G. NEW OPPORTUNITIES FOR IMMUNOLOGICAL CONTROL OF THE EFFECTIVENESS OF VACCINATION AGAINST COVID-19. Medical News of North Caucasus. 2021;16(2):232-233. DOI - https://doi.org/10.14300/mnnc.2021.16054

Для цитирования: Кетова Г. Г. НОВЫЕ ВОЗМОЖНОСТИ ИММУНОЛОГИЧЕСКОГО КОНТРОЛЯ ЭФФЕКТИВНОСТИ ВАКЦИНАЦИИ ПРОТИВ COVID-19. Медицинский вестник Северного Кавказа. 2021;16(2):232-233. DOI - https://doi.org/10.14300/mnnc.2021.16054 
T he importance of the article "Assessment of IgG-dependent humoral and cellular immunity in people who have recovered from COVID-19 and in healthy volunteers" presented by a group of authors from scientific organizations of the city of Stavropol is beyond doubt [1]. Indeed, the emergence of COVID-19 has posed challenges for healthcare professionals to diagnose and provide medical care to patients quickly. Currently, numerous research groups throughout the world participate in intensive studies of the clinical and epidemiological characteristics of the disease and the development of new means of its prevention and treatment. One of the challenges before them is the development of vaccines both for the long-term protection of people at high risk of getting COVID-19, such as medical workers and for rapid use in the case of an outbreak [2]. At the same time, it is evident that to assess the immune status of people who have recovered from COVID-19 and those who have been vaccinated, and new diagnostic systems are needed. The article under analysis is devoted precisely to solving this problem: clinical studies of an original test system developed by Stavropol scientists.

Currently, the following vaccines are registered in the Russian Federation for the specific prevention of $\mathrm{CO}$ VID-19 in adults:

- combined vector vaccine («Gam-COVID-Vac»), registration date 11.08.2020;

- combined vector vaccine («Gam-COVID-Vac-Lyo»), registration date 25.08.2020;

- vaccine based on peptide antigens («EpiVacCorona»), registration date 13.10.2020.

Since January 18, 2021, mass vaccination of the population against COVID-19 is being carried out in the Russian Federation [3].

In preparation for vaccination against COVID-19, laboratory tests for the presence of IgG and IgM immunoglobulins to the SARS-CoV-2 virus are not mandatory. At the same time, people who have positive test results for the presence of IgG and IgM immunoglobulins to the SARSCoV-2 virus that were obtained independently on the preparation for vaccination are not vaccinated according to the Interim Guidelines.

Speaking at the Council of Rectors on 08/28/2020, the head of the Federal Service for Surveillance on Consumer Rights Protection and Human Wellbeing (Rospotrebnadzor), Anna Popova, said that the immunity to coronavirus infection was found in $24-26 \%$ of the tested Russians. It is also known that the immunity to corona- virus infection can develop in patients who did not have any disease symptoms. For example, studies carried out in January 2021 in the city of Chelyabinsk showed that $1.5-2 \%$ of city residents had COVID-19 without symptoms.

The Ministry of Health of the Russian Federation developed a standard operating procedure that establishes the rules for organizing the work of medical organizations (or their structural units) and medical workers who carry out vaccination against COVID-19 in adults [4]; the vaccination procedure is described in. The SOP clearly defines the indications and contraindications for components I and II and the categories of people, the decision on vaccination, which should be taken with caution [5].

In typical clinical practice, information on the strength of immunity to SARS-CoV-2 is essential. Therefore, the development of various test systems to obtain data on the strength of immunity to SARS-CoV-2 has begun in Russia. In this regard, of interest for practical medicine are diagnostic ELISA test systems developed by the staff of the Scientific Production Association «Immunotex» (Russia): they make it possible to determine the level of neutralizing IgG in the blood serum and the content of antigen-recognizing receptors of B-lymphocytes of the peripheral blood represented by membrane IgG to SARS-CoV-2.

The diagnostic ELISA test system described in the study [1] allows detecting the levels of blocking IgG in the serum and the content of antigen-recognizing receptors of B-lymphocytes of the peripheral blood represented by IgG to the trimeric S-protein of SARS-CoV-2 in asymptomatic people and in people who believe that they were not infected with Covid-19 [3]. Importantly, this study shows that a decrease in serum IgG to the trimeric S-protein of SARSCoV-2 does not mean eliminating immunological protection against viral infection. Instead, it can be assumed that repeated contact with the virus will cause the mobilization of memory B-lymphocytes and the production of specific immunoglobulins.

Thus, when organizing vaccination of the populace to ensure their maximum protection against possible infection with the new SARS-CoV-2 coronavirus and to prevent possible severe consequences of the disease, medical workers need to take into account the categories of people who currently have contraindications to vaccination: such are pregnant women, children up to the age of 18 , people with severe chronic pathologies and autoimmune disorders. The information obtained on the strength of immunity to SARS-CoV-2 in this category of patients using the developed diagnostic ELISA test system will contribute to the adequate planning of clinical, rehabilitation, and dispensary activities by primary care physicians.

Disclosures: The authors declare no conflict of interest.

References

1. Baturin V. A., Grudina E. V., Zagrebailova N. D., Baturin M. V., Fil A. A. [et al.] Evaluation of IgG-dependent humoral and cellular immunity in persons after COVID-19 and in healthy volunteers. Medical News of North Caucasus. 2021;16(1):27-30 https://doi.org/10.14300/mnnc.2021.16007

2. WHO Working Group - Target Product Profiles for COVID-19 Vaccines. 17 April 2020. Available at: https:// www.who.int/publications/m/item/who-working-group-target-product-profiles-for-covid-19-vaccines.

3. Temporary guidelines. Prevention, diagnosis and treatment of a new coronavirus infection (COVID-19) of the Ministry of Health of the Russian Federation. Version 10
(08.02.2021). Available at: https://static-0.minzdrav.gov.ru/ system/attachments/attaches/000/054/662/original/Bpeменные MP COVID-19 \%28v.10\%29.pdf.

4. Muravyeva A. A., Obedin A. N., Zinchenko O. V., Vladimirova O. V., Mazharov V. N. [et al.] Experience in treatment of patients with the new coronavirus infection - COVID-19 complicated with pneumonia in the intensive care department of a city hospital. Medical News of North Caucasus. 2020;15(3):404-407

https://doi.org/10.14300/mnnc.2020.15096

5. Letter of the Ministry of Health of Russia dated 09.12.2020 N17-0/and/2-18965 «On the procedure for vaccination against COVID-19 in the adult population».

https://www.consultant.ru/law/hotdocs/66575.html/

\section{About author}

Ketova Galina Grigorievna, DMSc, Professor, Department of polyclinic therapy and clinical pharmacology

tel.: +73517218255; e-mail: galina_ketova@mail.ru 